\title{
A Cúpula para o Desenvolvimento Social, Saúde e a América Latina
}

A

Cúpula para o Desenvolvimento Social (CDS), convocada pela Organização das Nações Unidas (ONU) e realizada em março deste ano, significa que pela primeira vez o desenvolvimento social comparece como tema global.

E se, de um lado, ela representa um significativo avanço no debate mundial na medida em que esteve centrada na pessoa humana e nas noções de igualdade e eqüidade, de outro lado ela evidencia, no que diz respeito à presença latino-americana, a contradição básica entre as políticas econômicas atuais de estabilidade e de ajuste e a prioridade do desenvolvimento social.

Nesse sentido, pode-se aventar a hipótese de que a imagem latino-americana no cenário mundial transmitida pelos distintos países foi a de um continente marcado por problemas econômicos que prevalecem sobre as questões sociais. Devese registrar, por exemplo, a ausência de Chefes de Estado de países economicamente mais expressivos, como Brasil, México e Argentina; a presença marcante somente do Brasil e do Chile nas negociações dos documentos forais da CDS; e a natureza dos documentos oficiais apresentados à ONU pelos diferentes países, que oscilam entre o tom burocrático e o oficialesco dos respectivos relatórios. No que diz respeito a este ponto em particular, registre-se que o caso brasileiro foi uma exceção, apresentando um relatório que retrata de maneira corajosa e fiel a situação social do país, fato este destacado no pronunciamento do Ministro Paulo Renato de Souza, Chefe da Delegação Brasileira.

Vale registrar, ainda, que foi iniciativa do Brasil a inclusão de um décimo compromisso na Declaração firmada pelos países, relativos à educação e ao acesso de todos à assistência básica de saúde. Este compromisso, no documento que diz respeito ao Programa de Ação é detalhado em termos, por exemplo, do combate à mortalidade infantil, dentre outros.

No entanto, a despeito dos avanços realizados, evidencia-se um percurso conservador no que diz respeito às resoluções sobre os recursos nacionais e internacionais, destinados à promoção do desenvolvimento social, predominando negociações bilaterais sobre temas como perdão da dívida externa, por exemplo.

Mas ao mesmo tempo que se evidencia esse desequilíbrio entre intenções e esforços de compromissos efetivos com o financiamento de ações voltadas para o desenvolvimento social, evidenciase também que o próprio tema, pela sua amplitude, dificulta essa articulação mais estreita entre ambos. $\mathrm{E}$ isso apesar de o desenvolvimento social, pela agenda da CDS, ter sido organizado em torno de três grandes núcleos temáticos: combate à pobreza, criação de empregos produtivos e integração de grupos socialmente vulneráveis.

Esse fato aponta para a importância das Conferências futuras já agendadas sobre temas específicos, como mulher e hábitat. Estas terão nos resultados da CDS uma pauta de avanços já conquistados, e que por sua vez possibilitarão, através das questões específicas que tratam, impulso nos compromissos ali assumidos.

Por fim, deve ser realçado o fato de que o processo de elaboração do documento oficial brasileiro, para o qual foram realizados três seminários, pôs em evidência a importância da participação da comunidade científica no processo de interlocução entre governo, comunidade acadêmica e sociedade. Isso porque não só é impossível se ter políticas eficazes e eficientes de alívio e superação da pobreza sem diagnósticos competentes da situação social em seus distintos aspectos e de avaliação das diferentes políticas, como foi essa interlocução que possibilitou que o documento brasileiro, embora apresentado à ONU por um governo, acabasse se revelando um documento da sociedade brasileira.

\section{Amélia Cohn}

Departamento de Medicina Preventiva, Faculdade de Medicina, Universidade de São Paulo Editora Associada dos Cadernos de Saúde Pública 


\section{The World Summit on Social Development, Health, and Latin America}

$\mathrm{T}$ he World Summit on Social Development (WSSD) convened by the United Nations (UN) in March this year meant that social development was emerging as a global issue for the first time in history.

While the Summit was a significant step forward in the world debate to the extent that it focused on human beings and the notions of equality and equity, in the Latin American context it also laid bare the essential contradiction between current economic stabilization and adjustment policies and social development as a priority.

In this sense, one can raise the hypothesis that the Latin American image transmitted by various countries in various ways in the world scenario was one of a continent marked by internal economic problems prevailing over social issues. For example, one noted the absence of heads of state from the most economically significant countries, like Brazil, Mexico, and Argentina, the fact that only the Brazilian and Chilean delegations were present in the negotiations over the Summit's final position papers, and the very nature of the official documents submitted to the UN by the various countries, wavering between a bureaucratic and officialist tone in their final reports. In all fairness, we should say that Brazil was an exception to this last point, having submitted a report that was a courageously precise portrait of the country's social situation, as stressed in the speech by Minister Paulo Renato de Souza, head of the Brazilian delegation.

We should also recall that Brazil took the initiative to include a tenth commitment in the Declaration signed by the nations, relating to education and universal access to basic health care. In the document pertaining to the Action Program, this commitment was spelled out in terms of the struggle against infant mortality, among other issues.

However, notwithstanding such progress, the Summit took a conservative approach to resolutions concerning both national and international resources devoted to promoting social development, where bilateral negotiations prevailed over issues like pardoning of the foreign debt.

Still, even while there was a clear imbalance between intentions and efforts at effective commitments to funding actions devoted to social development, it was also clear that the social development issue itself, due to its very broad nature, hampers such a close link between intentions and efforts. And this despite the fact that the Summit agenda organized the approach to social development along three major thematic lines: the struggle against poverty, creation of productive jobs, and integration of socially vulnerable groups.

This fact underscores the importance of future Summit Conferences already planned on specific themes, like those devoted to women and the habitat. Such conferences will be able to draw from WSSD a number of important steps that have already been taken and will in turn lead to further progress in the commitments made on those specific issues.

Finally, we should emphasize the fact that the drafting process for the official Brazilian document, backed by three prior seminars revealed the important role played by the scientific community in this dialogue between government, the academic community, and civil society. The reason for this is twofold: because it is impossible to have effective and efficient policies for overcoming poverty without competent diagnoses of both the social situation in its various dimensions and the respective policies, and because this dialogue meant that the Brazilian position paper, albeit submitted to the $\mathrm{UN}$ by the Brazilian government, proved to reflect Brazilian society as a whole.

\section{Amélia Cohn}

Departamento de Medicina Preventiva, Faculdade de Medicina, Universidade de São Paulo Associate Editor of Cadernos de Saúde Pública 